\title{
The Good Sinful Ruler: Ambrose of Milan and Theodosius I
}

The first major innovation in imperial representation inspired by Christianity surfaced more than half a century after the death of Constantine. ${ }^{1}$ The actions of two prominent figures from this time jointly led to this change. Ambrose (c. 339-397) - the bishop of the imperial residence Milan - was certainly the initiator of this influential political development. ${ }^{2}$ However, Theodosius I's (347-395) own role in establishing this new element of imperial representation should not be underestimated. ${ }^{3}$ The emperor's act of repentance which he had to perform publicly in 390 or 391

1 This study was conducted within the framework of the project "“Centers' and 'Peripheries"” in Medieval Europe as part of the program for foundational research at the National Research University Higher School of Economics (Moscow) for the year 2017.

2 Among the copious amount of research literature, see especially: Wirtz R. Ambrosius und seine Zeit. Trier, 1924; Campenhausen H.v. Ambrosius von Mailand als Kirchenpolitiker. Leipzig, 1929; Palanque J.-R. Saint Ambroise et l'empire romain. Paris, 1933; Dudden F.H. The Life and Times of Saint Ambrose. Vol. 1-2. Oxford, 1935; Paredi A. Sant'Ambrogio e la sua età. Milano, 1940; Morino C. Chiesa e stato nella dottrina di s. Ambrogio. Rome, 1963 (English Translation: Morino C. Church and State in the Teaching of St. Ambrose. Washington, D.C., 1969); Courcelle P. Recherches sur saint Ambroise. "Vies" anciennes, culture, iconographie. Paris, 1973; Gottlieb G. Ambrosius von Mailand und Kaiser Gratian. Göttingen, 1973; Storoni Mazzolani L. Ambrogio vescovo. Chiesa e impero nel IV secolo. Milano, 1992 (= Il Cammeo, 229); McLynn N.B. Ambrose of Milan. Church and Court in a Christian Capital. Berkeley. Los Angeles 1994 (= The Transformation of the Classical Heritage, 22); Williams D.H. Ambrose of Milan and the End of the Nicene-Arian Conflict. Oxford, 1995; Ramsey B. Ambrose. London, 1997; Moorhead J. Ambrose. Church and Society in the Late Roman World. London / New York, 1999; Sordi M. L'impero al tempo di Ambrogio. Milano, 2000 (= Collana La zattera, 2). Also: Diesner H.J. Kirche und Staat im ausgehenden vierten Jahrhundert: Ambrosius von Mailand, in: Idem. Kirche und Staat in spätrömischem Reich. Berlin, 1963. p. 22-45; Schneemelcher W. Kirche und Staat im 4. Jahrhundert. Bonn, 1970; Barnes T. Religion and Society in the Age of Theodosius, in: Grace, Politics and Desire: Essays on Augustine / Ed. by Hugo A. Meynell. Calgary, 1990. p. 157-175; Dassmann E. Ambrosius von Mailand: Leben und Werk. Stuttgart, 2004.

3 In addition to the numerous articles in encyclopaedias and other general reference works, see especially: Güldenpenning A., Ifland J. Der Kaiser Theodosius der Große, ein Beitrag zur römischen Kaisergeschichte. Halle, 1878; Dölger F.J. Kaiser Theodosius der Große und Bischof Ambrosius von Mailand in einer Auseinandersetzung zwischen Predigt und Meßliturgie, in: Antike und Christentum. Vol. 1. Münster, 1929. p. 54-65; Egger R. Der erste Theodosius, in: Byz. Vol. 5. 1930. p. 9-32; Enßlin W. Die Religionspolitik des Kaisers Theodosius des Großen. Munich, 1953; Greenslade S.L. Church and State from Constantine to Theodosius. London, 1954; King N.Q. The Emperor Theodosius and the Establishment of Christianity. Philadelphia, 1960; Lippold A. Theodosius I, in: RE Supplementband 13. Munich, 1973. p. 837-961; Idem. Theodosius der Große und seine Zeit. Munich, 1980 (= Urban-Bücher, 107); Mellon D.B. Theodosius and the Conversion of the Roman Pagan Aristocracy. Michigan, 1984; De Giovanni L. La politica religiosa di Teodosio I, in: Rassegna di diritto romano. Vol. 40. 1994. p. 102-111; Klein R. Theodosius der Große und die christliche Kirche, in: Eos. Vol. 82. 1994. p. 84-121; Williams St., Friell G. Theodosius. The Empire at Bay. L., 1994; Lizzi Testa R. La po-

D OpenAccess. (c) 2021 Mikhail A. Boytsov, published by De Gruyter. (cc))BY-NC-ND This work is licensed under the Creative Commons Attribution-NonCommercial-NoDerivatives 4.0 International License. 
became a very important precedent that has remained firmly embedded in ecclesiastical history and has become a point of reference in various political contexts even into the early modern period. ${ }^{4}$ This episode in Milan influenced Ambrose and Theodosius' contemporaries and their descendants to such a degree that the demonstration of humilitas has ever since that time become one of the cardinal virtues of a true Christian ruler.

Although scholarly literature on the repentance of Theodosius is extensive, some important aspects of this politically symbolic act and its transmission have, surprisingly, received little attention. The following pages will attempt to highlight facets of this episode that have so far not been sufficiently discussed and scrutinised. The first part discusses if Ambrose can really be seen as a spokesman for outrageous "public opinion": the stance he obviously intended to take. Parts two, three and four focus on Ambrose's famous letter to Theodosius. Although most modern scholars have seen the "theological" sections of this work as a less important assortment of biblical quotations, this article will demonstrate that they actually constituted the political core of Ambrose's message. The fifth part revisits an old question: What might the emperor's penance have looked like? Or, at the very least, how did his contemporaries or their descendants imagine it? Finally, the sixth part will attempt to explain how and to what end Ambrose transformed his own public image of Theodosius as a penitent into the model of the perfect ruler, a model that would remain influential for centuries.

\section{Manipulating the Church Synod}

The trigger for the bishop of Milan's ground-breaking initiative was the rather brutal retaliation against the inhabitants of Thessalonica following a riot in the spring or perhaps summer of 390. Exactly what occurred and to what extent the emperor was personally responsible for the massacre cannot be accurately reconstructed due to vague, conflicting and for the most part highly biased accounts. A new analysis of the transmission of the dramatic events in Thessalonica would require its own comprehensive study that is beyond the scope of this paper. The following assumption will suffice for the present study: unlike ecclesiastical historians of the fifth century, modern scholarship tends to regard the excesses of 390 as the result of highly

litica religiosa di Teodosio I. Miti storiografici e realtà storica, in: Rendiconti della Classe di Scienze morali, storiche e filologiche dell'Accademia die Lincei. Ser. 9. Vol. 393. 1996. p. 323-361; Ernesti J. Princeps christianus und Kaiser aller Römer. Theodosius der Große im Lichte zeitgenössischer Quellen. Paderborn; Munich; Vienna; Zürich, 1998 (= Paderborner Theologische Studien, 25); Leppin H. Theodosius der Große. Auf dem Weg zum christlichen Imperium. Darmstadt, 2003; Maraval P. Théodose le Grand (379-395); le pouvoir et la foi. Paris, 2009; Lançon B. Théodose. Paris, 2014.

4 See foremost: Schieffer R. Von Mailand nach Canossa: ein Beitrag zur Geschichte der christlichen Herrscherbuße von Theodosius d. Gr. bis zu Heinrich IV, in: DA. Vol. 28. 1972. p. 333-370. 
unfortunate circumstances, perhaps even random chance, rather than an outcome of a direct imperial order. ${ }^{5}$

In scholarly literature, Ambrose always appears as a bold representative of public opinion, alarmed by the events in Thessalonica. A synod was in session in Milan at the time, and Ambrose states that among the bishops of northern Italy at the synod "there was no one who did not lament, nobody who took it (the news of the massacre - M.B.) lightly." 6 This was because nobody could recall anything comparable to what had happened in Thessalonica. ${ }^{7}$ This is the perspective on these events found in the most important source: Ambrose's well-known letter to Theodosius. ${ }^{8}$ It had been aptly noticed that this letter "is not an account of the events but is itself an important part of them." ${ }^{9}$ While the transmission of the letter is problematic, its authenticity is not in doubt. ${ }^{10}$ However, the question of whether the original text

5 Larson C.W.R. Theodosius and the Thessalonian Massacre Revisited - Yet Again, in: Studia patristica. Vol. 10. 1970. p. 297-301; McLynn (cf. fn. 2) 315-330; Groß-Albenhausen K. Imperator christianissimus. Der christliche Kaiser bei Ambrosius und Johannes Chrysostomos. Frankfurt a.M., 1999 (= Frankfurter althistorische Beiträge, 3). p. 113-114; Just P. Imperator et Episcopus: Zum Verhältnis von Staatsgewalt und christlicher Kirche zwischen dem 1. Konzil von Nicaea (325) und dem 1. Konzil von Konstantinopel (381). Stuttgart, 2003 (= Potsdamer Altertumswissenschaftliche Beiträge, 8). p. 200; Leppin (cf. fn. 3) 154-155; Kelly Ch. Ruling the Later Roman Empire. Cambridge (Mass.), 2009. p. 223; Doležal S. Rethinking a massacre: What really happened in Thessalonica and Milan in 390?, in: Eirene. Vol. 50 (1-2). 2014. p. 89-107.

6 Quando primum auditum est, propter adventum Gallorum episcoporum synodus convenerat, nemo non ingemuit, nullus mediocriter accepit [...] - Ambr., epist. 11(51).6. Cited following the edition of: Sancti Ambrosi Opera. Pars X. Epistulae et acta / Rec. O. Faller et M. Zelzer. T. 3. Vienna 1982 (= CSEL 82/3). English translation according to: Ambrose of Milan: Political Letters and Speeches / transl. by J.H.W.G. Liebeschuetz with the assist of C. Hill. Liverpool, 2005.

7 Factum est in urbe Thessalonicensium quod nulla memoria habet. - Ibid.

8 The surviving text does not contain a date. It is generally assumed that the letter must have been composed around the 10th of September 390. There are two reasons for this assessment: Firstly, the text refers to a comet that was visible from the 22nd of August until the 17th of September. Secondly, the emperor could not have returned to Milan until after the 8th of September, as this is the date recorded on his last edicts from Verona (VI id. Sept). See, Palanque (cf. fn. 2) 538. This reasoning has not convinced everyone. Later attempts have again dated the incidents at Thessalonica to the spring of 390: Lippold (cf. fn. 3) 888.

9 Schieffer (cf. fn. 4) 339: "nicht einen Bericht über die Ereignisse darstellt, sondern selber ein wesentlicher Bestandteil des Geschehens [...] ist."

10 Ambrose originally decided not to include this letter - and the 15 others - in the collection of Epistulae he was preparing for publication. Otto Faller and later Michaela Zelzer developed the hypothesis that Ambrose modelled his collection on Pliny's Epistulae, which is why he set aside the "political" letters for the tenth and last book. For the justification, see Zelzer's introductions to volumes 2 and 3 of the standard edition: Sancti Ambrosi Opera. Pars X. Epistulae et acta / Rec. O. Faller et M. Zelzer. T. 1-4. Vienna 1968-1996 (CSEL 82/1-4), as well as an array of articles published by the authors in the Anzeiger der philologisch-historischen Klasse of the Akademie der Wissenschaften in Vienna and the Wiener Studien. Richard Klein supported this idea and connected the publication of the tenth book to Theodosius' death in 395: Klein R. Die Kaiserbriefe des Ambrosius. Zur Problematik ihrer Veröffentlichung, in: Athenaeum. N.S. Vol. 48. 1970. p. 335-371, here p. 364-365. Howev- 
was retrospectively edited by the author or not has been a regular point of debate. ${ }^{11}$ When was the letter published? Did Paulinus - Ambrose's secretary - succeed in publishing the letter shortly after the bishop's death? ${ }^{12}$ Or did the letter caused by the dramatic events at Thessalonica remain hidden even from him, not resurfacing until the ninth century ${ }^{13}$ In any case, the letter is included in only few manuscripts and was very rarely cited until the nineteenth century.

A close reading of the letter allows us to ascertain that Ambrose's role was far more important than merely that of an advocate or spokesperson of church dignitaries. Contrary to all previous scholarship, he appears to have been the very person deliberately suggesting the "correct" opinion to the other bishops. The introductory passage of the letter in which Ambrose narrates how he himself acquired knowledge of the dramatic events in Thessalonica has so far received surprisingly little attention. The emperor had forbidden others to pass on any information concerning the discussions within his consistorium to Ambrose. (Historians agree that he placed this restriction on Ambrose as a direct consequence of their dispute about the destruction of the synagogue of Callinicum two years earlier.) ${ }^{14}$ However, Ambrose continues: nihil esse occultum, quod non manifestetur - nothing is hidden that shall not

er, other scholars doubt the assumption that Ambrosius tried to imitate the structure of Pliny's Epistulae and assume that his intentions must have been quite different. See: Mazières J.P. Une principe d'organisation pour le recueil des Lettres d'Ambroise de Milan, in: Ambroise de Milan. XVI ${ }^{\mathrm{e}}$ Centenaire de son élection épiscopale. Études augustinnienes. 1974. p. 199-218; Idem. Les Lettres d'Ambroise de Milan à Irenaeus, in: Pallas. Vol. 26. 1979. p. 103-114; Savon H. Saint Ambroise a-t-il imité le recueil de lettres de Pline le Jeune?, in: Revue des Études Augustiniennes. Vol. 41. 1995. p. 3-17. The hypothesis that Ambrose's collection of letters was influenced by that of Pliny seems to have gained acceptance in spite of these contradictions, see, e. g., Ambrose of Milan: Political Letters and Speeches / transl. by J.H.W.G. Liebeschuetz with the assist of C. Hill. Liverpool, 2005 (2nd ed. 2010). p. 31-36. Page 39 of this publication contains a surprising argument for the authenticity of the letter: "Its extremely diplomatic formulation does suggest that it is a real letter, which was actually sent to the emperor."

11 Zelzer assumes that the letter remained unchanged, as Ambrose had not wanted to publish it. By way of contrast, Klein makes the case that while Ambrose did edit the text, he then decided not to publish it: Klein (cf. fn. 10) 353-355.

12 Klein (cf. fn. 10) 355, 367-370. Similar Schieffer (cf. fn. 4) 346.

13 Zelzer M. Prolegomena, in: Sancti Ambrosi Opera... T. 3. P. CXV; Zelzer K., Zelzer M. Befunde und Probleme lateinischer Tradition, in: Zeitschrift für Antikes Christentum. Vol. 8. 2004. p. 107-126, here p. 125.

14 Palanque (cf. fn. 2) 223; Enßlin (cf. fn. 2) 62-63, 67-68. A plausible reconstruction of the events at Callicinum can be found in older literature: Barth G. Ambrosius und die Synagoge zu Callinicum, in: Theologische Zeitschrift aus der Schweiz. Vol. 6. 1889. p. 65-86; De Labriolle P. Saint Ambroise et l'affaire de Callinicum, in: Revue des Cours et Conférences. Vol. 16. 1898. p. 76-86. On this point, Moorhead (cf. fn. 2) 192-193 is misleading. The authors of more recent literature do not exclude the possibility that the order not to inform Ambrose of important political affairs was given a year later, after the argument about the Altar of Victory (389): Liebeschuetz (cf. fn. 10) 225; Schulz F. Ambrosius, die Kaiser und das Ideal des christlichen Ratgebers, in: Historia - Zeitschrift für Alte Geschichte. 2014. Vol. 63. H. 2. p. 214-242, here p. 225. 
be made manifest. ${ }^{15}$ He had had an informant in the imperial council, whose name he did not wish to divulge, so as to protect him from potential danger. ${ }^{16}$ The emperor's wrath could conceivably have even threatened the informant's life. The bishop speaks openly of wanting to prevent bloodshed by his silence. ${ }^{17}$

What "public opinion" is indicated here? Ambrose thought it necessary to explain to the emperor how he came to be informed of something that had been discussed in the consistorium. The council had not been held in Milan, as Theodosius himself resided elsewhere at this time (probably in Verona). ${ }^{18}$ Ambrose's personal "agent" in the emperor's entourage must have sent his secret messenger to Milan with great haste to be able to inform the bishop of the proceedings. The only plausible interpretation is that Ambrose was at first the only person in Milan who knew of the massacre in Thessalonica. This inevitably leads to the conclusion that Ambrose wanted to use the church synod to put the emperor under political pressure in order to regain at the very least easy access to the ruler. Neither official messages, nor rumours could have reached the assembled bishops without Ambrose's initiative; the affair was being kept strictly secret. It seems obvious that Ambrose took the liberty of presenting the message in a way that seemed most suitable to him.

He did not merely inform his colleagues of the dramatic events in a neutral manner - far from it. He had to manufacture a "public opinion," to recruit factioneers for his impending confrontation with the emperor and to obtain rhetorically a justification so that he could refer not only to his own opinion but to that of the synod - essentially the opinion of the church. This is echoed by Rufinus: according to him Theodosius was not condemned by Ambrose alone but by the "bishops of Italy."19 Ambrose certainly had good reasons to expect the support of the bishops of northern

15 Ambr., epist. 11(51).2.

16 [...] ne eos qui in suspicionem proditionis venerint dedam periculo. - Ambr., epist. 11(51).2.

17 Sed quod in tuis iussis timerem, in meis verbis deberem cavere, ne quid cruentum committeretur. Ambr., epist. 11(51).3.

18 Seeck O. Regesten der Kaiser und Päpste für die Jahre 311 bis 476 n. Chr. Stuttgart, 1919. p. 277-278. Frank Kolb's assumption that the emperor only left Milan so as to escape the pressure Ambrose was putting him under probably goes too far: Kolb F. Der Bußakt von Mailand: zum Verhältnis von Staat und Kirche in der Spätantike, in: Geschichte und Gegenwart: Festschrift für Karl Dietrich Erdmann / Ed. by Hartmut Boockmann. Neumünster, 1980. p. 41-74 here p. 49. However, it has been adopted by scholars: Leppin (cf. fn. 3) 157 (the conflict between bishop and emperor was also dated differently: before, rather than after Theodosius was in Verona). It seems more realistic that Theodosius was either occupied in Verona with Alemannic issues or - as his predecessors had done - was merely escaping the summer heat of Milan: McLynn (cf. fn. 2) 323, note 112.

$19 \mathrm{Ob}$ hoc cum a sacerdotibus Italiae argueretur, agnovit delictum. - Rufin. 2(11).18. (Cited according to the edition PL. Vol. 21. Paris, 1878). Augustine, who had left Milan in 387, of course received news from the city with an "Ambrosian" spin, mirrored in his own note on Theodosius' penitence (Aug., civ. 5.26). The "Ambrosian" position is also generally adopted by recent scholarship. E. g.: Leppin (cf. fn. 3) 155. 
Italy, insofar as they recognised him as their unofficial leader on other issues. ${ }^{20}$ The question remains: were his expectations met?

Contrary to Ambrose's account, most bishops' reactions to his demand were probably more cautiously guarded than supportive. In any case, we know of no voice in their circle that supported Ambrose's position. The bishops did not, for example, decide to wait a few days for the imminent return of the emperor to deliver a more powerful admonition together. Neither did they compose a joint appeal to Theodosius in which they could have expressed their concerns in careful and courteous words. The synod was apparently calmly disbanded and left the bishop of Milan behind to wait alone for the return of his imperial spiritual son. In this context it is easier to understand why Ambrose felt compelled to fall back on his usual "last resort" when in conflict with any of his rulers: to simply leave the situation behind. Ambrose then left Milan, justified by the completely fictitious grounds (as he himself admits) of having fallen ill, and escaped to Aquileia two or three days before Theodosius' arrival in Milan. ${ }^{21}$ Aquileia was the second most important episcopal see in northern Italy and its powerful bishop Chromatius was Ambrose's friend. ${ }^{22}$ It is likely that he actually supported Ambrose in this precarious political matter, unlike perhaps most of his colleagues. It was in Aquileia that Ambrose composed his letter to the emperor, partially dictated, partially in his own hand.

\section{Admonishing the New David}

Despite all this, Ambrose starts his epistula with the "memory of old friendship [that] is sweet" that connects him to Theodosius. ${ }^{23}$ Scholarship cannot confirm whether there ever was such an affectionate relationship between Ambrose and his addressee. Ambrose did not even gain entry to the circle of intimate imperial councils. ${ }^{24}$ The old "friendship" was probably mentioned for rhetorical reasons only. Both in medieval and ancient times, the word amicitia was often used to describe a relationship between unequals. Ambrose however, as Jörg Ernesti has brought to light, developed his own understanding of amicitia. He speaks of an equal status (aequalitas) among friends, even if they have different social positions, and of it being imperative

20 For Ambrose's dominant role among northern Italian bishops, see especially: Lizzi R. Ambrose’s Contemporaries and the Christianisation of Northern Italy, in: JRS. Vol. 80. 1990. p. 156-173; McLynn (cf. fn. 2) $276-290$.

21 Praetendi aegritudinem corporis revera gravem et nisi a viris mitioribus vix levandam vel emori tamen maluissem quam adventum tuum biduo aut triduo non expectaram. - Ambr., epist. 11(51).5. 22 Lizzi (cf. fn. 20) 165.

23 Et veteris amicitiae dulcis mihi recordatio est [...] - Ambr., epist. 11(51).1.

24 On this, see: Groß-Albenhausen (cf. fn. 5) 115. "Zu keinem Kaiser hatte Ambrosius ein wirkliches Vertrauensverhältnis" - Schulz (cf. fn. 14) 226. 
to return wayward friends to the right path through admonition (monitio). ${ }^{25}$ In his letter to Theodosius, Ambrose could have been referring to this very concept of friendship, in which the inferior party within the official hierarchy is empowered to point out the superior party's mistakes and to admonish him in private.

Ambrose remembers with gratitude the favours Theodosius had often bestowed upon various persons following the bishop's intercession. ${ }^{26}$ (However, this sentence could also be understood to mean that Ambrose felt he himself had never profited from the emperor's favours on account of either his own unselfishness or the emperor's reserve towards his person.) Theodosius should understand that it was not ingratitude that induced the bishop to be absent on the emperor's arrival. In fact, his presence had always been much desired by the bishop. ${ }^{27}$ It has rarely been remarked in scholarly literature that this probably referred to the adventus domini, the formal arrival ceremony in which the local bishop was almost obliged to take part. ${ }^{28}$ Ambrose's absence during this official act of state would have been understood by many as a public act of protest. He admits as much in his letter and promises to explain his reasons in the subsequent lines. ${ }^{29}$

Then Ambrose addresses Theodosius as a shepherd might his sinful congregant: "If the priest will not admonish the wrongdoer, the wrongdoer will die in his guilt but the priest will be liable to punishment because he did not warn the wrongdoer." ${ }^{30} \mathrm{By}$ taking the conversation to this level ("Listen to this, august emperor!") 31 he changes Theodosius' would-be political misstep into a sin he is compelled to call out in his

25 Ernesti (cf. fn. 3) 175-176. Vgl. Ambr., off. 3.22.133. The standard edition: Sancti Ambrosii Episcopi Mediolanensis opera / Ed. Gabriele Banterle. Vol. 13. Milano; Rome, 1977. p. 354. On this work, see: Zelzer K. Randbemerkungen zu Absicht und Arbeitsweise des Ambrosius in De officiis, in: $\Sigma$ ФAIPО $\Sigma$. Hans Schwabl zum 70. Geburtstag gewidmet. Vienna, 1994/1995 (= WSt. Bd. 107/108. 1994/1995). T. 2. p. 481-493, including further bibliographical information.

26 [...] beneficiorum, que crebris meis intercessionibus summa gratia in alios contulisti -Ambr., epist. 11(51).1.

27 Unde colligi potest quod non ingrato aliquo affectu adventum tuum semper mihi antehac exoptatissimum decliner potuerim. - Ambr., epist. 11(51).1.

28 For more detail, see: Dufraigne P. Adventus Augusti, Adventus Christi. Recherche sur l'exploitation idéologique et littéraire d'un cérémonial dans l'antiquité tardive. Paris, 1994; Lehnen J. Adventus principis. Untersuchungen zu Sinngehalt und Zeremoniell der Kaiserankunft in den Städten des Imperium Romanum. Frankfurt a. M. etc., 1997 (= Prismata, 7). The adventus ceremony is not identical to the Roman triumph, despite many similarities. As an example for recent scholarship on the later Roman triumph, see: Pfeilschifter R. Der römische Triumph und das Christentum, in: Der römische Triumph in Prinzipat und Spätantike / Ed. by Fabian Goldbeck, Johannes Wienand. Berlin; N.Y., 2016. p. 455-486. McLynn rightly points out that Ambrose must have meant a public ceremony: McLynn (cf. fn. 2) 326. However, he regards it as no more than a purely formal act at court, which could not have had any public meaning.

29 Sed qua causa hoc fecerim breviter expediam. - Ambr., epist. 11(51).1.

30 Si sacerdos non dixerit erranti, is qui erraverit in sua culpa morietur et sacerdos reus erit poenae, quia non admonuit errantem. - Ambr., epist. 11(51).3.

31 Accipe illud, imperator auguste. - Ambr., epist. 11(51).4. 
function as bishop. The cause of this sin was the imperfection inherent to Theodosius' human nature: he was too impulsive and irate. ${ }^{32}$ (Here we find the roots of that "psychologising" rationalisation of the Thessalonian catastrophe of which later church historians continuously try to persuade their readers.)

And what is more: Ambrose stylises the punitive action following the riot in Thessalonica as a rebellion against God, meaning Theodosius now urgently needed to seek reconciliation with God. ${ }^{33}$ He must do this without his bishop's council or mediation. Ambrose leaves the emperor to stand alone before the countenance of his irate God - a very precarious position. However, the bishop offers the emperor an appropriate example of a sinner who finally reconciled with God: King David. The political instrumentalisation of David is one of Ambrose's greatest theoretical and rhetorical achievements. "Contemporary" rulers had previously not been compared regularly to Old Testament kings. Whether this was due to the anti-Jewish attitude of the first Christian emperors, as has been suggested by Eugen Ewig, ${ }^{34}$ remains to be seen. In any case, it is thanks to Ambrose that David gradually became a universal topos in the description of Christian rulers. (Later Ambrose may even have dedicated a treatise with the title Apologia David to the emperor, which he probably wrote in 386 or 387.$)^{35}$

Ambrose had previously compared Theodosius to David during their earlier conflict on the synagogue of Callinicum on the Euphrates. In the letter he wrote on this event, the bishop asks the emperor: "And what will Christ say to you after this? Do you not remember the instructions he gave to the holy king David through Nathan the prophet?"36 Immediately afterwards, Ambrose appealed to his addressee in his own passionate speech in the style of the Old Testament prophet (2 Sm 7:8-16). The roles had been clearly assigned even then. Theodosius was compared to King David while Ambrose practically merged himself with Nathan, so that the emperor would hear the words of none other than Jesus Christ in the bishop's letter.

32 [...] sed habes naturae impetum, quem si quis lenire velit cito vertes ad misericordiam, si quis stimulet in maius exsustitas ut eum revocare vix possis. - Ibid.

33 [...] dei nostri reconciliationem fore necessarium. - Ambr., epist. 11(51).6.

34 Ewig E. Das Bild Constantins des Großen in den ersten Jahrhunderten des abendländischen Mittelalters, in: HJb. Vol. 75. 1956. p. 1-46, here p. 5.

35 For its dating see: Leppin H. Das Alte Testament und der Erfahrungsraum der Christen: Davids Buße in den Apologien des Ambrosius, in: Die Bibel als politisches Argument: Voraussetzungen und Folgen biblizistischer Herrschaftslegitimation in der Vormoderne / Ed. by Andreas Pecar, Kai Trampedach (= HZ / Beihefte NF, 43). Munich, 2007. p. 119-133, here p. 131-133. For previous dating attempts see ibid. p. $125 \mathrm{fn}$. 25. On account of the date it was written the treatise cannot be connected to the episode at Thessalonica: (ibid. p. 131). The authenticity of the dedication to Theodosius is also debated. See also Schulz (cf. fn. 14) 226.

36 Et quid tecum posthac Christus loquetur? Non recordaris quid David sancto per Nathan prophetam mandaverit? - Ambr., epist. 74.22. Of course, it was not Christ who spoke to David through Nathan but Sabaoth; however, Ambrose equates these two persons of the Christian Trinity. 
In his letter from Aquileia in 390, Ambrose further develops the theme of David the Sinner in a long section with abundant biblical quotations. It is especially interesting to see how the bishop interpreted this theme and which features he chose to highlight. David had to do penance humbly on two occasions. The first occasion occured after he took the beautiful Bathsheba for himself while sending her husband Uriah to his death (2 Sm 11-12; Ps 51). The second time was after he evoked the Lord's anger by trying to conduct a census in Israel and Judah (2 Sm 24:1-10; 1 Chr 21:1-9). However, David's subsequent remorse did not protect him from having to pay a high price for his misdeeds. In the first case, his and Bathsheba's firstborn son died. In the second, 70,000 Israelites fell victim to a plague.

Ambrose begins the long "biblical" part of his letter with the question of whether Theodosius can bring himself to do what David did. For the latter had confessed: "I have sinned against the Lord" (2 Sm 12:13). However, Ambrose does not describe the circumstances of David's confession. He mentions neither the adultery (which would not really have been fitting in this instance), ${ }^{37}$ nor the murder of Uriah the Hittite, deliberately provoked by David (which would have been quite suited to the occasion). Instead, Ambrose retells the parable Nathan used to open David's eyes to his injustice: A rich man had owned many flocks but had taken and slaughtered a poor man's only sheep to prepare and serve for his guest. ${ }^{38}$ What does this parable have to do with the events at Thessalonica? Why does Ambrose assert "you have done what the prophet had told King David that he had done"? ${ }^{39}$ The bishop of Milan's version is slightly more dramatic than the one later included in the Vulgate: Ambrose says the rich man occidit the sheep, whereas in the Vulgata he first tulit viri pauperis and then praeparavit cibos. ${ }^{40}$ In Ambrose's version, the sheep somehow needed to be comparable to the inhabitants of Thessalonica. An attempt of explaining this passage is possible under the assumption that the execution of punitive mea-

37 Theodosius married Galla the daughter of Emperor Valentinian I in 387. It would have been in Ambrose's interest to avoid any parallels between Bathsheba and Galla, so as not to cast the suspicion of adultery on the latter. This would have been a grave accusation which could have cost Ambrose too much.

38 An pudet te, imperator, hoc facere quod rex propheta auctor Christi secundum carnem prosapie fecit David? Illi dictum est quia dives qui haberet plurimos greges unam pauperis ovem propter adventum hospitis eripuit et occidit [...]. - Ambr., epist. 11(51).7.

39 Tu fecisti istud quod David regi dictum est a propheta. - Ambr., epist. 11(51).7.

40 Ambrose used different early Latin versions of the Scriptures, but also followed the text of the Septuaginta and other Greek translations of the Bible. Mannix M.D. Introduction, in: Idem. Sancti Ambrosii oratio de obitu Theodosii. Text, Translation, Introduction and Commentary. Diss. Washington, D.C., 1925. p. 6-7. In one place, he even mentions that, for him, Greek manuscripts have greater authority (potior auctoritas): Hušek V. The True Text: Ambrose, Jerome, and Ambrosiaster on the Variety of Biblical Versions, in The Process of Authority. The Dynamics in Transmission and Reception of Canonical Texts / Ed. by Jan Dušek, Jan Roskovec. Berlin; Boston, 2016, p. 319-336, here p. 323. The bishop was fluent in Greek, perhaps even as a second native tongue: his family had possibly moved to Rome from the East. 
sures in Thessalonica was entrusted to troops of Goths. ${ }^{41}$ In this case, those very Goths could be equated to the hospes for whom the sheep was killed. Assuming this interpretation is correct, this passage could be understood as Ambrose's protest not only against the punitive action in Thessalonica but also against the entirety of the emperor's friendly politics towards the Goths, whom Ambrose considered heretical Arians.

\section{Placing Demands on the Emperor}

Immediately after the charge of murder, Ambrose unveils the path to "reconciliation with God" to the emperor:

For if you listen to this attentively and say: I have sinned against the Lord, if you repeat that royal and prophetic saying: $O$ come, let us worship and fall down before him, and let us weep before the Lord our maker [Ps 95:6], you too will be told: 'Because you have repented, the Lord will forgive your sin and you shall not die. ${ }^{42}$

The last sentence is also borrowed from Nathan's words to David (2 Sm 12:13) but not completely. Ambrose added the conditions for forgiveness - this was obviously especially important to him: quoniam poenitet te. But then he discontinues the quotation for reasons easily discerned. Nathan continues: "Nevertheless, because by this deed you have utterly scorned the enemies of the LORD, the child that is born to you shall die." ${ }^{43}$ Openly threatening the emperor with the death of one of his three sons would, of course, have been imprudent. Could Ambrose, however, have assumed that Theodosius would know the scripture well enough to perceive its macabre context?

Regardless, the bishop immediately proceeds to David's second act of repentance. This time, he describes the reason in detail and even explains why conducting a census was a sin against God (because that knowledge should belong only to the Lord). He narrates how David was offered the chance to choose his own punishment and how the one he chose was indeed carried out. However, in his letter Ambrose simply changes the prophet Gad, through whom God disclosed his will to King

41 A couple of decades ago, Frank Kolb explained both the conflict in Thessalonica and Ambrose's position with the fact that the massacre must have been committed by the Goths: Kolb (cf. fn. 18) 49-50. This opinion has since been widely adopted, see Leppin (cf. fn. 3) 153. However, Stanislav Doležal recently emphasised that it is basically pure speculation: Doležal (cf. fn. 5) 102-103.

42 Noli ergo impatienter ferre, imperator, si dicatur tibi: Tu fecisti istud quod David regi dictum est a propheta. Si enim hoc sedulo audieris et dixeris: Peccavi domino, si dixeris regale illud propheticum: Venite, adoremus et procidamus ante eum et ploremus ante dominum nostrum qui fecit nos, dicetur et tibi: Quoniam poenitet te, dimittet tibi dominus peccatum tuum et non morieris. - Ambr., epist. 11(51).7.

432 Sam 12:14. In the Vulgata this passage is phrased as: Verumtamen quoniam blasphemare fecisti inimicos Domini, propter verbum hoc, filius qui natus est tibi, morte morietur. 
David in this Bible passage, into Nathan, thereby underlining the deliberate parallelism between himself and this prophet. ${ }^{44}$

He again carefully quotes David's confessions while silently skipping over other, obviously irrelevant details of the biblical text. First, when David confesses his transgression the first time: "I have sinned greatly in that I have done: and now, I beseech thee, O LORD, take away the iniquity of thy servant; for I have done very foolishly" (2 Sm 24:10; 1 Chr 21:8). This last part is phrased slightly more dramatically by Ambrose than in the Vulgate: "because I have sinned exceedingly." 45 Was this how the passage appeared in the Vetus Itala Ambrose used or did he himself change the quote to have the desired effect?

Ambrose subsequently quotes David's second confession, made when he saw the angel annihilating his people:

Lo, I have sinned, and I have done wickedly: but these sheep, what have they done? Let thine hand, I pray thee, be against me, and against the house of my father. (2 Sm 24:17; $1 \mathrm{Chr}$ 21:17).

Ambrose breaks off the citation at this point, even though the passage in Chronicles continues: "but not on thy people, that they should be plagued." Without this mitigating ending the threat against "the house of my father" must have seemed even more impressive.

In his elaborate depiction of both of David's acts of repentance, Ambrose is obviously phrasing his own demands of the emperor: Theodosius must confess his sin and repent. The next section differs strongly in style from what Ambrose had written previously. Instead of a more or less detailed depiction of moralising episodes four(!) passages of three(!) different Old Testament books are cited in succession without the slightest explanation of their respective contexts. The first passage has absolutely nothing to do with David and is a loose (perhaps too loose) paraphrase of two verses from the Book of Job (31:33 - 34): "I have not hidden my sin but declared it before all the people." 46 Then, without any transition the author abruptly returns to the theme of David who is now, however, presented in a completely different light. David no longer appears as villain and sinner. He is, on the contrary, first and foremost the possible victim of a crime and then also the very person judging a murder. Ambrose cites the words Jonathan spoke to his father, the "barbaric" King Saul (1 Sm 19:4-5): "Do not sin against your servant David" and "why do you sin against innocent blood

44 Iterum cum plebem numerari iussisset David, percussus est corde et dixit ad dominum: Peccavi vehementer quod fecerim hoc verbum, et nunc, domine, aufer iniquitatem servi tui quod deliqui vehementer. Et missus est iterum ad eum Nathan propheta qui ei trium optionem conditionum offerret ut quam vellet eligeret [...] Culpa autem erat quoniam voluit scire numerum totius plebis que secum erat, quod scire deo soli debuit reservare. - Ambr., epist. 11(51).8-9.

45 Ego peccavi et ego pastor malignum feci et hic grex quid fecit? Fiat manus tua in me et in domum patris mei. - Ambr., epist. 11(51).9.

46 Iob sanctus et ipse potens in saeculo ait: Peccatum meum non abscondi sed coram plebe omni annuntiavi. - Ambr., epist. 11(51).10. 
to slay David without a cause?"47 This is directly followed by Ambrose's explanation: "For though he was king he would nevertheless sin if he slew an innocent man." However, the author does not elaborate on his comment and instead proceeds straight to a new example: David was king by this time and heard of the death of the innocent Abner by Joab's hand (2 Sm 3:28). David said: "I and my kingdom are now and forever innocent of the blood of Abner, son of Ner" - et ieiunavit in dolore (and he fasted in grief) Ambrose added in his own words. ${ }^{48}$

This section is an inconsistently composed "patchwork" that can only be comprehended in light of the hypothetical reconstruction of the bishop of Milan's method. But the reverse is also true: the inner logic of these few lines must be understood first to be able to arrive at a hypothetical reconstruction. Apparently, Ambrose composed his argument in a first step and only then - in the second step - started to look for the "suitable" passages and examples in the Scriptures. These were not merely illustrations but also powerful arguments. Even though nothing about this method was original or individual, the morphology of the letter to Theodosius enables us to trace this rhetorical practice in a more nuanced manner.

Thus, it seems Ambrose daws up three (veiled) requirements for the emperor in the "biblical part" of his epistula. First, a ruler who has sinned against God must admit his guilt and repent. This assertion is, as has been shown above, supported by a succession of Bible passages. Second, the ruler's repentance must be public. (The passage about Job who was relentlessly tested serves as the only argument here.) Third, Ambrose defines exactly what Theodosius should repent of: the emperor's $\sin$ is the murder of innocents, as even kings are forbidden to spill innocent blood.

Considering these three requirements, framed with the help of Bible passages, the sections just examined (7-10) must be counted among the most central. This core of the letter has so far been largely ignored by scholarship, because the "biblical part" seems at first glance to be merely a chaotic mixture of quotations from the Bible. The letter has primarily been mined for "specific historic events," mostly in the preceding or following passages in which the author does not hide behind the lines of the Old Testament. For example, a recent study devoted a total of fourand-a-half pages to this famous letter to Theodosius. The "biblical part" of the letter warranted no more than the following statement in the eyes of the author: "Theodosius should not be ashamed to do what David had also done. He should confess that he has sinned and show his remorse, for he is likewise only a human being." ${ }^{49}$

47 Ipsi immani regi Saul dixit Ionathas filius suus: Noli peccare in servum tuum David, et: Ut quid peccas in sanguinem innocentem occidere David sine causa? - Ambr., epist. 11(51).10.

48 Denique etiam David cum iam regno potiretur et audisset Abner innocentem occisum a Ioab duce militiae suae ait: Innocens sum ego et regnum meum amodo et usque in aeternum a sanguine Abner filii Ner, et ieiunavit in dolore. - Ambr., epist. 11(51).10.

49 Groß-Albenhausen (cf. fn. 5) 116: "Theodosius sollte sich nicht schämen, das zu tun, was auch David getan habe: Er solle bekennen, dass er gesündigt habe, und bereuen, denn er sei auch nur 


\section{Veiled Threats}

The sentence "You are a man and temptation has come your way. Conquer it!"50 already belongs to a new section in which Ambrose describes how the emperor must fulfil his demands.

I have written these things [i.e., including the three requirements presented before - M.B.] not to embarrass you but so that these examples involving kings ${ }^{51}$ may induce you to lift this burden of sin from your kingship; and you will lift it by humbling your soul before God. ${ }^{52}$

Pointing to the fact that the emperor is human, Ambrose further asserts that "Sin cannot be abolished otherwise than by tears and penitence," ${ }^{33}$ which unambiguously means that the personal repentance of the emperor is the only possible solution in this case. No one can plead or intercede with God on Theodosius' behalf in this precarious affair, not even an angel or archangel (nec angelus potest nec archangelus). ${ }^{54}$

It cannot easily be determined whether Ambrose merely threatened the emperor with excommunication, ${ }^{55}$ or whether Theodosius was in fact excommunicated when Ambrose refused to give him the Eucharist. ${ }^{56}$ The fine differences in ecclesiastical law

ein Mensch." Similarly McLynn (cf. fn. 2) 325-326 and even more briefly: Klein (cf. fn. 10) 354. Anm. 42; King (cf. fn. 3) 69, Banterle G. Due momenti di crisi nei rapporti tra Teodosio e S. Ambrogio, in: Atti e memorie della Accademia di agricoltura, scienze e lettere di Verona. Anno 1984/1985. Serie VI. Vol. 36. p. 243-252, here p. 249 ("Ricorda l'esempio di Davide, che si pentí delle sue colpe e le parole di Gionata a Saul per esortarlo a non macchiarsi di sangue innocente..."). More emphasis is placed on the "biblical part" in a different study, however, the scholar tends to be searching for parallels with the Apologia David: Ernesti (cf. fn. 3) 179-181.

50 Homo es et tibi venit temptatio, vince eam. - Ambr., epist. 11(51).11.

51 Ernesti has quite rightly pointed out that this passage simply concerns kings in general, without specifying the "Kings of Israel." However, he takes his hypothesis too far: "Indem Theodosius mit diesen verglichen wird, wird er in gewissem Sinne mit ihnen auf eine Stufe gestellt, in die Reihe der biblischen Könige eingeordnet.” - Ernesti (cf. fn. 3) 181.

52 Haec ideo scripsi non ut te confundam, sed ut regum exempla provocent ut tollas hoc peccatum de regno tuo; tolles autem humiliando deo animam tuam. - Ambr., epist. 11(51).11.

53 Peccatum non tollitur nisi lacrimis et poenitentia. - Ambr., epist. 11(51).11.

54 When Roger Gyson cites this passage as part of Ambrose's "general theory on repentance," he fails to take into account that this assertion that the angels and archangels would be powerless should by no means be understood in abstract theological terms, but rather in the context of specific and charged political events: the bishop of Milan did not want to fulfil his pastoral duties and act as Theodosius' advocate before God. Gryson R. Introduction, in: Ambroise de Milan. La Pénitence. Paris, 1971 (= Sources chrétiennes, 179). p. 37-38.

55 Campenhausen (cf. fn. 2) 238; King (cf. fn. 3) 69; Diesner (cf. fn. 2) 444; McLynn (cf. fn. 2) 326; Moorhead (cf. fn. 2) 193; "Es handelt sich lediglich um die Gewissensentscheidung des Bischofs." - Leppin (cf. fn. 3) 156.

56 Koch H. Die Kirchenbuße des Kaisers Theodosius d. Gr. in Geschichte und Legende, in: HJb. Bd. 38. 1907. p. 257-277, here p. 264. Anm. 1; Palanque (cf. fn. 2) 232, Larson (cf. fn. 5) 298; Ernesti (cf. fn. 3) 175; more cautiously worded: Dassmann (cf. fn. 2) 189 - "Ambrosius hatte zwar keine för- 
for which historians continuously search were probably not defined with such precision until the Carolingian period. The word excommunicatio does not appear in connection to the events in Thessalonica neither in any of Ambrose's own nor in any other approximately contemporary authors' writings. ${ }^{57}$ On the other hand, excommunication in the early church meant no more than exclusion from participation in the liturgy and the sacraments. In this way, Paulinus related the heart of the matter correctly when he wrote that Ambrose refused the emperor coetus ecclesiae uel sacramentorum communio. ${ }^{58}$ The urge to mark the expulsion of a sinner from the church with some kind of ritual in which candles would be extinguished emerged much later - probably not until the Carolingian period. ${ }^{59}$ There is, however, another reason excommunication was less formidable around the year 400 than during the High Middle Ages: it did not automatically entail the withdrawal of the official rank of the excommunicated person. The kings on whom an interdict was imposed in the eleventh or thirteenth centuries were essentially relieved of their throne through this action alone (even if they themselves, as is well-known, never wanted to accept this dismissal automatically). Ambrose, however, did not question Theodosius' right to continue ruling even without taking part in communion. What he did do was to leave the emperor alone before the countenance of his irate God in such a way that might lead to severe political and perhaps also familial catastrophes.

Ambrose utters no direct threats, but perhaps he implies between the lines that both the emperor's military successes and his offspring could be struck by God's wrath. Hartmut Leppin is right in surmising that the last lines of the letter, in which Ambrose wishes that the emperor and his children may enjoy lasting peace, contain "a threat regarding family misfortunes that had to be taken seriously." ${ }^{60}$ It has been shown above that there are at least two further passages in the text in which it can be assumed the author hints at possible risks to the emperor and his family - not by what he says, but by what he leaves in silence.

Furthermore, the bishop's strongly articulated amor towards Gratian seems especially significant. At this time Gratian, the youngest of Theodosius' three sons and the first born of his second wife, must have been one and a half or two years old. ${ }^{61}$ If mentioning Gratian was really meant as a threat, then it was in fact fulfilled, even if this was a mere coincidence: Gratian would die three or four years after the

mliche Exkommunikation ausgesprochen, aber daß die Übernahme der Buße Bedingung für eine Wiederzulassung zur Eucharistie sein würde, daran ließ der Brief keinen Zweifel.”

57 Schieffer (cf. fn. 4) 350.

58 [...] nec prius dignum iudicauit coetu ecclesiae uel sacramentorum communione [...] - Paulin., v. Ambr. 24.

59 Jungmann J.A. Die lateinischen Bußriten in ihrer geschichtlichen Entwicklung. Innsbruck, 1932 (= Forschungen zur Geschichte des innerkirchlichen Lebens, 3/4). p. 44-74. Especially p. 63-64. 60 Leppin (cf. fn. 3) 156-157: "sehr ernst zu nehmende Drohung mit Unglücksfällen in der Familie." 61 Rebenich S. Gratian, a Son of Theodosius, and the Birth of Galla Placidia, in: Historia - Zeitschrift für Alte Geschichte. Vol. 34. 1985. p. 372-385. Unlike in much early scholarship, Gratian was here correctly identified as Theodosius' son: Dassmann (cf. fn. 2) 248. 
dispute over the massacre at Thessalonica. Thus, the same thing happened to Theodosius as had previously happened to his "model" David.... Perhaps this was the reason for the harmonious relations between the emperor and the bishop during the last years of Theodosius' reign. Perhaps after such a brutal proof the emperor had to accept the fact that he in fact was the new David, while Ambrosius was the new Nathan.

Even if the significant emphasis on Gratian was a later addition during Ambrose's final years while he was, as some historians believe, preparing his letters for publication and editing them in the process, this assertion nevertheless illuminates the author's thought. In this case, the bishop who already knew the tragic fate of Gratian would have used the name of the child to depict himself retrospectively as a prophet, as the new Nathan, who had reproached his new David and shown him the right path with rather drastic measures. This would be a very convincing indicator that scholars do not err when they assume that veiled threats were hidden between Ambrose's pious lines.

Irrespective of whether the letter is authentic or was considerably changed by the author post festum, the bishop's demand for the emperor to recognise his sin and repent did not elevate Theodosius above other Christians in the eyes of the bishop or his contemporaries. Its goal was simply to restore the lost "normal" status of the sinner within the Christian community. The fact that the repentance had to be publicly observed did not guarantee the emperor any advantages. On the contrary, he had to expect hefty sacrifices that the irate God would demand of him.

\section{Witnessing the Emperor's Repentance}

As is generally known, the emperor decided to yield and comply with the Bishop of Milan's demands. What might Theodosius' penance have looked like? Theodoret of Cyrrhus who probably wrote shortly after the year $444,{ }^{62}$ provides a detailed but fanciful account, in which he mainly expresses his own complicated relations to Emperor Theodosius II. He does however mention the eight months the emperor had spent mourning in his palace before he finally decided at Christmas to reconcile with Ambrose and the church. These chronological details have had a hypnotic effect on scholars: almost no other word of Theodoret's account is trusted - and with good reason - but an exception is made for either the "eight months" or "Christmas." As these two statements are difficult to reconcile, scholars are split into two parties. Proponents of the first assume that Theodosius must have spent eight months in penance (even though in Theodoret's report the emperor did not spend this time re-

62 Chesnut G. The Date and Composition of Theodoret's Church History, in: VCHr. Vol. 35. 1981. p. 245-252 (attempting to date this text by Theodoret between the years 441 and 449) and Croke B. Dating Theodoret's Church History and the Commentary on the Psalms, in: Byz. Vol. 54. 1984. p. $59-74$. 
penting but rather slowly realising that he could not avoid public penance). ${ }^{63}$ The second party views Christmas as the time of reconciliation following repentance. ${ }^{64}$ However, some scholars point out that the custom of the Milanese Church was not to readmit people concerned into the sacramental community until Holy Thursday. ${ }^{65}$ Others speculate that Ambrose could have made an exception for the emperor admitting him to communion earlier at Christmas. ${ }^{66}$

Whether it was eight or three months of penance, would either have been considered a long or short period for repentance? On the one hand, it was surely too little as the canons of the church on the sin of homicide require 5, 7, 10, 20 years or even lifetime penance ${ }^{67}$ On the other hand, this particular act of repentance did not concern an ordinary person, but the ruler of the whole Roman Empire. ${ }^{68}$ Modern scholars like to speculate on how much time would have been sufficient for the emperor's repentance, but they have done so without taking a source into consideration which provides a nearly contemporaneous view on this much debated issue. The highly popular "hagiographical novel" about emperor Constantine's conversion, the Actus Silvestri - the "Deeds of Sylvester" - was probably written in Rome between 390 and $500 .{ }^{69}$ The long-promised critical edition of the two original versions has un-

63 McLynn (cf. fn. 2) 328 indicating a further mention of the eight-month period in a different letter of Ambrose. See, Ambr., epist. 76(20).27.

64 For a relatively recent example, see: Bellen $H$. Christianissimus Imperator. Zur Christianisierung der römischen Kaiserideologie von Constantin bis Theodosius, in: E fontibus haurire. Beiträge zur römischen Geschichte und zu ihren Hilfswissenschaften. / Ed. by Rosmarie Günther, Stefan Rebenich (= Studien zur Geschichte und Kultur des Altertums. NF. 1. Reihe. Bd.8.). Paderborn etc., 1994. p. 3-19, here p. 17-18.

65 Frank H. Ambrosius und die Büßeraussöhnung in Mailand. Ein Beitrag zur Geschichte der mailändischen Gründonnerstagsliturgie, in: Heilige Überlieferung. Ausschnitte aus der Geschichte des Mönchtums und des heiligen Kultes (Festschrift für I. Herwegen). Münster, 1938. p. 136-173. This paper concluded the long-running debate whether the reconciliation of sinners in Milan was conducted on Holy Thursday or Good Friday. This question is of a more general significance than it seems at first glance. If it took place on Good Friday, the liturgical practices of Milan would have been in stark contrast to those of Rome, as the latter forbade the consecration of bread and wine on Good Friday and Holy Saturday. See also: Jungmann (cf. fn. 59) 7, 74-109 for evidence about the Roman church, however most of it concerning the fifth through twelfth centuries. For the compromise solution: either Christmas or Holy Thursday, see Leppin (cf. fn. 3) 158.

66 Gryson (cf. fn. 54) 42, Anm. 2.

67 Koch (cf. fn. 56) 275. Anm. 2; Campenhausen (cf. fn. 2) 240.

68 Groß-Albenhausen (cf. fn. 5) 135.

69 Pohlkamp W. Textfassungen, literarische Formen und geschichtliche Funktionen der römischen Silvester-Akten, in: Francia. Bd. 19. Teil 1. 1992. p. 149. Concerning the dating of the episode on Sylvester binding the dragon to roughly 400, see: Idem. Tradition und Topographie: Papst Silvester I. (314-335) und der Drache vom Forum Romanum, in: RQ. Vol. 78. 1983. p. 35, 38, 40. Contrary to the opinion of Pohlkamp, Garth Fowden insists on an oriental (Greek) origin of the principle motifs of the Actus Silvestri on account of Armenian analogies. He also put forward a suggestion of how Eusebius the bishop of Nicomedia, who really christened Constantine, became Sylvester, bishop of Rome, in the Actus: Fowden G. The Last Days of Constantine: Oppositional Versions and Their Influ- 
fortunately not yet been published, ${ }^{70}$ but the main elements of the story are known well enough for our purposes from outdated editions. ${ }^{71}$ The anonymous author of the Actus Silvestri expresses his own conception of how a penitent emperor should behave. This notion is in itself valuable, and it cannot be ruled out that it was even shaped by real events. The literary Constantine in the Actus Silvestri had to atone for the brutal persecution (including executions) of Christians, basically the same grave sin as the historical Theodosius. ${ }^{72}$ It would have been difficult to write about the repentance of an emperor without considering the only historical instance of such an act of repentance either consciously or subconsciously. This act would have taken place merely several decades before and was probably generally known not only in Milan but also in Rome: In its time it caused a genuine sensation. Both of the earliest versions of the "Deeds of Sylvester" name the same period for Constantine's penance: seven days. Of course, it does not follow that Theodosius penance necessarily lasted the same length of time. However, it could be deduced from this account that a one-week repentance was, in the eyes of Theodosius' younger contemporaries, or those of the next two generations respectively (the exact time in which the Actus Silvestri was written is still unknown) enough for a ruler - even for an emperor who had spilled innocent blood.

The way a sinful emperor should spend his days of repentance is also described in the Actus Silvestri. He should withdraw into his palace, fast and exchange his purple clothes and diadem for sackcloth. He should also pray continuously, occasionally prostrate himself on the ground in sacco et cinere - in sackcloth and ashes.

Ambrose himself remembered with satisfaction four years later that Theodosius had also laid down his imperial regalia. ${ }^{73}$ Both Rufinus $^{74}$ and Sozomenos ${ }^{75}$ later

ence, in: JRS. Vol. 84. 1994. p. 146-170. In a more recent work on the Actus Silvestri it is asserted that the principle motifs of the work were already circulating by the beginning of the fifth century, mainly in the Eastern Empire. Among them, the new account of the christening of Constantine must have been most important, as it exonerated him from the accusation of having been an Arian. Nevertheless, both of the earliest texts must have originated in Rome around the year 500. Canella T. Gli Actus Silvestri. Genesi di una leggenda su Costantino imperatore. Spoleto, 2006 (= Uomini e mondi medievali, 7).

70 For more detail, see: Pohlkamp W. Textfassungen, literarische Formen und geschichtliche Funktionen der römischen Silvester-Akten, in: Francia. Vol. 19. Part 1. 1992. p. 115-196.

71 De probatis sanctorum historiis, partim ex tomis Aloysii Lipomani..., partim etiam ex egregiis manuscriptis... / Collectis per F. Laurentium Surium Carthusianum. T. 6. Coloniae Agrippinae, 1575. p. 1052-1065; Mombritius B. Sanctuarium seu Vitae sanctorum. T. 2. Paris, 1910. p. 508-531.

72 [...] et poenitere multos sanctos dei occidisse [...] see: Mombritius (cf. fn. 71) 512.

73 Ambr., obit. Theod. 34: Stravit omne, quo utebatur, insigne regium. Cited according to: Sanctus Ambrosius. Opera. Pars VII / Rec. Otto Faller. Vienna, 1955 (= CSEL, 73). p. 388. (see also: Mannix M.D. Sancti Ambrosii oratio de obitu Theodosii. Text, Translation, Introduction and Commentary. Diss. Washington, D.C., 1925.).

74 [...] et in hoc sibi tempus adscriptum absque regali fastigio patienter implevit. - Rufin. 2(11).18. 
spoke of this episode in the same way. Whether the emperor also refrained from ruling during this period remains uncertain. The literary Constantine in the Actus Silvestri published new edicts daily. Why should the historical Theodosius not have done the same?

The ascetic practices the emperor carried out behind the walls of his sacrum palatium are not, however, of great interest to historians, but rather the concluding public ceremony, which was remembered for generations and ultimately greatly influenced the political culture of Christian Europe. Our informants - Ambrose, Rufinus and Augustine - convey more of an emotional impression of the ceremony than its actual details. How much of the general public might have witnessed the emperor's penitence? The emperor would probably have wanted to do penance in a palace chapel, ${ }^{76}$ whereas it was in the interest of the bishop to insist on the action taking place in the cathedral, the (at this time) newly-built Basilica Maior or Basilica Nova (the future, but no longer existent, Santa Tecla). Only in this location could the "entire populace" properly witness the emperor's penitence and Ambrose's triumph. Ambrose probably also was victorious in this regard: The whole of Milan must have observed the emperor's humiliation. Otherwise there would have been no need for the bishop to return to the episode on Sunday February 25, 395 during his eulogy at Theodosius' coffin.

\section{Elevation through Humiliation}

Thousands of people listened to the speech known to us as De obitu Theodosii: courtiers, clerics, the elites of Milan and military personnel. During this time - only a few months after Theodosius' bloody victory over the "usurper" Eugenius ${ }^{77}$ - the largest and most experienced army of the Roman Empire was stationed in Milan. To whom the throne of the western part of the Empire, or even in Constantinople itself, would belong was dependant on the whim of these troops. ${ }^{78}$ Theodosius' sudden death had

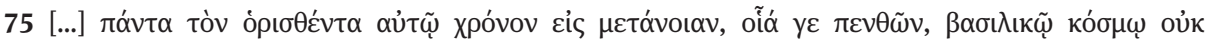

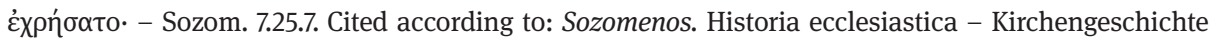
/ Ed. by Günther Christian Hansen. Teilbd. 1. Turnhout, 2004 (= Fontes Christiani, 73/1).

76 Should the new dating of San Lorenzo to the time of Stilicho's rule become established, this enigmatic church could of course no longer be considered a possible stage for the unprecedented scene of imperial penitence. See Löx M. Die Kirche San Lorenzo in Mailand: Eine Stiftung von Stilicho?, in: $\operatorname{MDAI}(\mathrm{R})$. Vol. 114. 2008. p. 407-438.

77 In detail, see: Szidat J. Die Usurpation des Eugenius, in: Historia - Zeitschrift für Alte Geschichte. Vol. 28. 1979. p. 487-508.

78 On Ambrose's funeral oration, see: Bonamente G. Potere politico e autorità religiosa nel 'De obitu Theodosii' di Ambrogio, in: Chiesa e Società dal secolo IV ai nostri giorni. Studi storici in onore del P. Ilarino da Milano. Vol. 1. Rome, 1979 (= Italia Sacra, 30). p. 83-133; Consolino F. E. L'optimus princeps secondo S. Ambrogio. Virtù imperatorie e virtù cristiane nelle orazioni funebri per Valentiniano e Teodosio, in: RSI. Vol. 96. 1984. p. 1025-1045; Eadem. Teodosio e il ruolo del principe cristiano dal De 
caused a political crisis whose outcome was at the time, on February 25, 395, not foreseeable.

Ambrose had chosen his side: he wanted to support Theodosius' sons as successors. The elder, Arcadius, resided then as he did later in Constantinople, outside of the bishop of Milan's range of influence. But the younger successor, ten-year-old Honorius, was present in Milan and nobody could be sure at that moment whether the army, court and people would support the child. Ambrose's speech was specifically geared towards making the transfer of power to Honorius possible - or more precisely, to a group of people around Honorius with the commanding general of the imperial army Stilicho at its head. The aims of this funeral oration, delivered in the presence of both the boy emperor and Stilicho, were clear and consistent. Its principle message was the necessary continuation of the Theodosian dynasty. ${ }^{79}$ Ambrose's general thrust can be summarised in three statements. First, Theodosius had been a great emperor and was well deserving of heavenly salvation. Second, he had not completely left the world; he had left behind his sons in whom it was possible to recognise and remember him. Third and finally, everybody (but above all the army) should serve these children as loyally as they had done the deceased emperor. $^{80}$

This otherwise coherent image had one dangerous flaw. Ambrose himself had presented the deceased emperor to the "public" of Milan as a sinner only a few years previously. No emperor before Theodosius had had to endure such an outrageous humiliation which could only mean that the deceased's violation of Christian norms must have been especially grievous. Did the emperor's rebellion against God not tarnish his sons, or even his whole kin? Ambrose deployed his entire eloquence to dispel these doubts among his listeners. A large part of the oration (26-38), contrary to the rules determining how such encomia should be worded, is dedicated to Theodosius' sins, but also to his humility - sometimes veiled, sometimes openly.

obitu di Ambrogio alle storie ecclesiastiche, in: Cristianesimo nella storia. Vol. 15. 1994. p. 257-278 (comparing the image of Theodosius in Ambrose's oration with that in the works of fifth-century historians); Biermann M. Die Leichenreden des Ambrosius von Mailand: Rhetorik, Predigt, Politik. Stuttgart, 1995 (= Hermes. Zeitschrift für klassische Philologie. Einzelschriften, 70). p. 103-119; 143-150; 178-191; Corsaro F. Il trono e l'altare. Da Costantino a Teodosio: De obitu Theodosii di Ambrogio, in: Vescovi e pastori in epoca teodosiana. In occasione del XVI centenario della consacrazione episcopale di S. Agostino, 396-1996. XXV Incontro di studiosi dell'antichità Cristiana. Vol. 2. Rome, 1997. p. 601-611; Sordi M. La morte di Teodosio e il 'De obitu Theodosii' di Ambrogio, in: Acta classica Debreceniensia. Vol. 36. 2000. p. 131-136. As a relevant preliminary study for the supposed new edition of the oration see: Zimmerl-Panagl V. Zu Überlieferung und Textgeschichte von Ambrosius' De obitu Theodosii (und Epistula extra collectionem 1), in: WSt. Vol. 129. 2016. p. 299-330.

79 See, e. g.: Palanque (cf. fn. 2) 293-294: “Cette idée de la perpétuité de la dynastie nous apparait précisément dominante dans le discours que l'évêque de Milan prononce aux obsèques de Théodose... ." Also ibid. 301-302; Klein (cf. fn. 10) 363; Mannix (cf. fn. 40) 3-4 and many others.

80 See in detail: Bojcov M.A. (Boytsov) Der Heilige Kranz und der Heilige Pferdezaum des Kaisers Konstantin und des Bischofs Ambrosius, in: FMSt. Vol. 42. 2008. p. 1-69. 
Thus, Ambrose returns here twice to Theodosius' penitence, arguably because this episode was still fresh in many of the attendants' minds. However, he infuses the event with a completely new meaning.

This time, the emperor does not appear as a sinner. On the contrary, Theodosius had been pious, just, merciful and deeply religious, hence he was about to enter the heavenly Jerusalem - a stark contrast to the contents of the Thessalonica letter. It now emerged that Theodosius "let reprieve forestall punishment," 81 that "he was more disposed to forgive especially when the passion of his anger had been particularly great." 82 He was so merciful towards the accused that "while holding supreme power over everyone, he would rather remonstrate like a parent than punish like a judge." 83 He had been a fair-minded judge with fair scales, not merely a dispenser of punishment, as he did not deny a pardon to those who confessed..$^{84}$ This image of Theodosius totally contradicted the one Ambrose had painted in his letter. The politically charged subtext is clear. Former supporters of the defeated Eugenius did not have to fear possible reprisals. The sons of the emperor were as lenient and merciful as their father had formerly been - another reason why they should eagerly be supported by all present.

What is more, Theodosius was probably at this very moment before Christ, interceding on behalf of his children ${ }^{85}$ - surely an assurance that the sons' reign would be prosperous. But Theodosius had also been humble, and humility was a precious commodity. ${ }^{86}$ He had humbly acknowledged his sins, giving the orator grounds to invoke a comparison to David. This time the comparison does not serve to criticise but to praise; David had also achieved salvation through humility. In fact, he is presented solely as the devoted head of his community. Ambrose cites the same passage as in his letter to Theodosius ( $2 \mathrm{Sm}$ 24:17; $1 \mathrm{Chr} 21: 17$ ), but the difference here is not merely that his translation now follows the Septuagint. ${ }^{87}$ More importantly, the passage is given a completely different meaning: "See it is I; I have sinned, I the shepherd have done wrong, and these in this flock, what have they done? Let your hand be against me." ${ }^{88}$ Ambrose breaks off at that point and does not continue with "and against the

81 [...] cum criminum poenas indulgentia praevenit. - Ambr., obit. Theod. 1.

82 Et tunc propior erat veniae, cum fuisset conmotio maior iracundiae. - Ambr., obit. Theod. 13.

83 Hoc erat remedium reorum, quoniam, cum haberet supra omnes potestatem, quasi parens expostulare malebat quam quasi iudex punire. - Ambr., obit. Theod. 13.

84 [...] aequitatis iudex, non poenae arbiter, qui numquam veniam confitenti negaret [...] - Ambr., obit. Theod. 13.

85 [...] speramus, quod liberis suis apud Christum praesul adsisitat [...] - Ambr., obit. Theod. 16. 86 Stravit omne, quo utebatur, insigne regium, deflevit in ecclesia publice peccatum suum, quod ei aliorum fraude obrepserat, gemitu er lacrimis oravit veniam. - Ambr., obit. Theod. 34.

87 For the Septuagint as the source for this wording, see: Sanctus Ambrosius. Opera. Pars VII... p. 384.

88 Ecce sum ego; peccavi, et ego pastor male feci, et isti in hoc grege quid fecerunt? Fiat manus tua in me. - Ambr., obit. Theod. 27. 
house of my father" which would have been anything but desirable while the transfer of power in Milan to Theodosius' younger son was still hanging in the balance.

At this point Theodosius is indirectly but clearly compared to Christ: "Christ humbled himself in order to raise up all. So he (David - M.B.) attained Christ's rest, when he imitated Christ's humility." 89 Ambrose had earlier drawn a parallel between the penitent David and Jesus, the humilitatis magister, who is both uerus humilis and aeternitate primus, humilitate ultimus. ${ }^{90}$ But at the time he had not pointed out that the humility of Christ resulted in the salvation of mankind. Here the parallels between David and Christ imply that Theodosius is the one who is prepared to sacrifice himself for his neighbours. A further hidden parallel to the Christological topos is observable in the description of Theodosius' public repentance discussed above, which must have been fresh in the minds of many in Ambrose's audience of 395. Through his humiliation he proved not only his superiority but also his willingness to suffer on behalf of others: Theodosius "threw to the ground all the royal attire he was wearing; he wept publicly in church over his sin which had stolen upon him through the deceit of others." 91 Theodosius thus bore his penance on behalf of others (who had advised him wrongly), which in turn made the analogies to David and Christ suitable. According to this interpretation, the penitence itself shifts from being a punishment - or at the very least an act of reconciliation - into the very embodiment of the emperor's piety, indeed almost the manifestation of his holiness.

The possibility of such a transition was not foreseeable from Ambrose's letter to Theodosius nor from his earlier elaborate work De penitentia. Ambrose touches on the subject in the Apologia David: the king opted for penitence even though private citizens usually did not wish to demonstrate such exemplary humility. However according to Ambrose's opinion at the time, the reward merely consisted of the immediate forgiveness of David's sins, not in his exceptional elevation or glorification. ${ }^{92}$ Essentially the same view is observable in some passages of the eulogy. For example, when it is asserted that "because Theodosius, the Emperor, showed himself to be humble and asked for forgiveness when sin stole upon him, his soul has returned to its rest." 93 This rest of the soul, this requies sabbati, is also emphasised in other passages of the speech. According to the bishop of Milan, Theodosius meets many

89 Humiliavit se Christus, ut omnes elevaret. Ipse ad Christi pervenit requiem, qui humilitatem fuerit Christi secutus. - Ambr., obit. Theod. 27. The parallel to Christ here as well as a new interpretation of humility as an imperial virtue are also briefly mentioned by Biermann (cf. fn. 78) 111, $113,115$. 90 This is noted in: Leppin (cf. fn. 35) 124 with reference to Ambr., apol. Dav. 17.81, cited according to: Ambroise de Milan. Apologie de David / Ed. Pierre Hadot. Paris, 1977 (= Sources chrétiennes, 239). 91 Quod privati erubescunt, non erubuit imperator, publicam agere paenitentiam [...] - Ambr., obit. Theod. 34.

92 Denique dominum dolor intimi mouit affectus, ut Nathan diceret: Quoniam paenituit te, et dominus transtulit peccatum tuum. Maturitas itaque ueniae profundam regis fuisse paenitentiam declarauit, quae tanti errores offensam traduxerit. - Ambr., apol. Dav. 2.5.

93 Et ideo, quia humilem se praebuit Theodosius imperator et, ubi peccatum obrepsit, veniam postulavit, conversa est anima eius in requiem suam [...] - Ambr., obit. Theod. 28. 
pious but not necessarily holy people: three generations of his own family, including the Emperors Constantine and Gratian. (Whether he could also communicate directly with Helena or whether she was part of a higher sphere remains unclear in Ambrose's account.) However, Ambrose then begins to approximate Theodosius' uncertain state to that of sanctitas. The "perfect" rest mentioned above had been assigned to saints. ${ }^{94}$ Theodosius had merited the fellowship of the saints ${ }^{95}$ and even now was happily dwelling in their midst, ${ }^{96}$ where the company of saints accompanied him. ${ }^{97}$ It is necessary, of course, to remember that the concept of holiness had not been completely worked out and standardised by the year 400. Exactly what Ambrose had in mind when he used the term sanctitas remains to be examined. It does seem quite clear, however, that the bishop of Milan's audience was presented with an image of Theodosius not as a pardoned sinner but rather as a saint who might already be standing before the throne of Christ as an intercessor on behalf of his two sons.

And so, it was on this day, February 25, 395, that the new notion was born that the humble, public penance of a ruler could not only contribute to the alleviation of his burden of sin but could furthermore lead to his spiritual elevation and almost to achieving religious perfection. For the first time in the context of imperial ideology the Christian humiliatio became exaltatio. It was certainly not inevitable that the penitence of the sinner in purple would be paradoxically reinterpreted as a moral accomplishment that elevated his person. Ambrose's letter to the emperor does not contain even a trace of the possibility that the repentance he demanded may lead to elevation. The ingenious bishop of Milan must have come up with the idea of making the public humiliation of the emperor an act that elevated the ruler later. The reason for this rather surprising change is not, however, necessarily rooted in Ambrose's theological deliberations, but is instead tied to his secular interests. It thereby seems that the topos of the elevation of a ruler following his humiliation was originally begun as an improvised means to influence the desired outcome of a specific (and fairly precarious) political situation. This new - and almost coincidental - discovery of the symbolism of imperial humilitas was, however, to have a grand future. ${ }^{98}$

94 Da requiem perfectam servo tuo Theodosii, requiem illam, quam preparasti sanctis tuis. - Ambr., obit. Theod. 36.

95 Ergo quia dilexit augustae memoriae Theodosius dominum deum suum, meruit sanctorum consortia. - Ambr., obit. Theod. 32.

96 Manet ergo in lumine Theodosius et sanctorum coetibus gloriatur. - Ambr., obit. Theod. 39.

97 [...] quem sanctorum turba prosequitur. - Ambr., obit. Theod. 56.

98 Concerning the further development of imperial humility as a means of both imperial representation and of exercising power, see: Leppin H. Power from Humility: Justinian and the Religious Authority of Monks, in: The Power of Religion in Late Antiquity / Ed. by Andrew Cain and Noel Lenski. Burlington, VT, 2009. p. 155-164. To bridge the gap to the High Middle Ages, see first: Althoff G. Die Macht der Rituale: Symbolik und Herrschaft im Mittelalter. Darmstadt, 2013 (2nd ed.). p. 104-130. The following study is recommended as an introduction to the late Middle Ages: Moeglin J.-M. Pénitence publique et amende honorable au Moyen Age, in: RH. 1997. Vol. 3. p. 225-270. 